\title{
Corinne Seeds and the Avenue 21 School: Towards a Sensuous History of Citizenship Education
}

\author{
Kathleen Weiler
}

In September 1911, a young graduate of the Los Angeles Normal School, Corinne Seeds, took a teaching job at the Avenue 21 School in one of the poorer areas of Los Angeles. Three years later, in 1914, she was made principal of the Avenue 21 Evening School for Adults, a position she held until 1920. Seeds later became the principal of the University Elementary School at UCLA and a nationally recognized leader in the progressive education movement. Corinne Seeds was one of thousands of young White native-born women teachers who taught in urban public schools and citizenship programs in the first two decades of the twentieth century. She described her years teaching immigrant and poor children and adults at the Avenue 21 School in an oral history interview conducted in the early 1960s. In this oral history, she provides an unusually vivid picture of her experiences. What does her narrative suggest about the role of public schools, the experiences of immigrant children, the work of white women teachers in this key period? How should we read her story?

Seeds' narrative provides evidence of the citizenship and literacy programs in public school systems during the great wave of immigration to North America in the early twentieth century. These new immigrants from Eastern and Southern Europe, Asia, and Mexico differed in language, religion, and "race" from the English-speaking Anglo-Saxons who made up the majority population and who held political and economic power. As P.P. Claxton, U.S. Commissioner of Immigration for the Department of

(C) Historical Studies in Education/Revue d'histoire de l'éducation 14, 2 (2002): 191-218 
the Interior, noted in 1913:

Most of the immigrants in recent years have little kinship with the older stocks of our population, either in blood, language, methods of thought, traditions, manners, or customs; they know little of our political and social life and are unused to our social ideals; their environment here is wholly different from that to which they have been accustomed. ${ }^{1}$

These immigrants made their journey in a period of rapid technological and economic change-indeed the technological innovations of the time made their migration possible. When they arrived in Canada and the United States, they entered societies in transformation-from rural to urban, from small-scale businesses to corporate capitalism, from a technology based on face-to-face encounters to one defined by distance through the inventions of the telegraph, telephone, automobile, and movies. And they were societies fundamentally organized by racism, in which ideas of race meant privilege or oppression, connotations of goodness and evil. ${ }^{2}$ In this world, the appearance of these very "foreign" foreigners raised anxieties and created the perception of social crisis. Their language, their customs, their very bodies challenged what was defined as normal and proper. In both Canada and the United States, settlement houses, schools, and literacy programs were envisioned as a means of creating responsible citizens from these

1 P.P. Claxton, "Letter of Transmittal," Education of the Immigrant, United States Bureau of Education, Bulletin No. 51, 1913, 5. For discussions of the education of immigrants in the United States see David Tyack, The One Best System (Cambridge: Harvard University Press, 1972); John Higham, Strangers in the Land (New York: Atheneum, 1967); Albert Shields, Bulletin 51: Evening Schools for Foreigners (Washington, D.C.: US Office of Education, 1913); United States Bureau of Education, Evening Schools for Foreigners: Bulletin 18 (Washington D.C.: U.S. Office of Education, 1916); United States Immigration Commission, The Children of Immigrants (Washington, D.C.: U.S. Office of Education, 1911); United States Bureau of Education Education of the Immigrant: Bulletin 13 (Washington, D.C.: U.S. Office of Education, 1913).

2 Toni Morrison, Dancing in the Dark (Cambridge: Harvard University Press, 1992). 
disparate and suspicious groups. ${ }^{3}$ In both countries, native-born White women worked as teachers and social workers at the intersection of gender, class, and race, symbolizing at the same time the power of whiteness and the subordination of womanhood. ${ }^{4}$ Seeds' narrative reveals the complexity of this encounter.

As in other North American cities, the moral panic over immigration in Los Angeles in the early twentieth century led to the establishment of programs to educate new citizens. These programs, which attracted immigrants, Mexican-Americans, and African-Americans, offered literacy classes as well as language and citizenship classes leading to naturalization. And, as was true in other cities, Americanization in Los Angeles depended on the work of women. Historians have analyzed the role of White, nativeborn women in the Americanization movement in the context of their involvement in progressive social reform more broadly-in the settlement house movement, the women's club movement, government agencies such as the Children's Bureau, and, of course, the suffrage movement. ${ }^{5}$ As numerous historians have noted, women reformers of this period tended to focus on the needs of women and children, thus in some sense remaining safely within the domestic sphere even when they were working in the very public sphere of the state. In her study of women and social

3 As Cathy James points out in her work on the settlement house movement in Toronto, the dynamics of race and class shaped the responses to the new immigrants there in much the same way as in the better-known settlements in Chicago and New York. Cathy James, "Reforming Reform: Toronto’s Settlement House Movement, 1900-1920," Canadian Historical Review 82, 1 (Mar. 2001): 55-90. See also Ken Osborne, "Public Schooling and Citizenship Education in Canada," Canadian Ethnic Studies/Études Ethniques au Canada XXXII 1 (2000): 8-37.

4 See Helen Harper, "White Women Teaching in the North: Problematic Identity on the Shores of Hudson Bay," in Dismantling White Privilege: Pedagogy, Politics and Whiteness, ed. N. Rodriguez and L. Villiaverde (New York: Peter Lang, 2000) for a contemporary discussion of this dynamic.

5 See, for example, Robyn Muncy, Creating a Female Dominion in American Reform (New York: Oxford University Press, 1991); Karen Blair, Clubwoman as Feminist: True Womanhood Redefined (New York: Holmes and Meier Press, 1980); Peggy Pascoe, Relations of Rescue (New York: Oxford, 1990); Theda Skocpol, Protecting Soldiers and Mothers (Cambridge: Harvard University Press, 1992). For California, see Gayle Gullet, Becoming Citizens (Urbana: University of Illinois Press, 2000). 
reform, Robyn Muncy calls this a "female dominion" of child welfare policy and reform. ${ }^{6}$ In the early twentieth century women's caretaking role was expanded to immigrants-adults as well as children. In the United States, such figures as Frances Kellor, vicechair of the National Americanization Committee, and Josephine Roche, head of the Division of Work with the Foreign Born during the First World War in the Wilson administration, helped set and administer national policy. ${ }^{7}$ In California, women were key figures behind the passage of the California Home Teacher Act of 1915, which focused on educating women about public health and the need for good drinking water, fresh milk, baths, and proper child care. $^{8}$

In Los Angeles, women, many of whom had participated in the settlement house movement, were central to the development of Americanization programs. $^{9} \quad$ The work of these women demonstrates a number of contradictions around race and gender, contradictions that were present in the Americanization movement nationwide. Americanization teachers were meant to teach the newcomers a belief in democracy and to integrate them into American society. ${ }^{10}$ The women teachers were almost exclusively white, while those they were "Americanizing” were seen as nonwhite, or, in the case of Jewish and Southern European immigrants,

6 Muncy, Creating a Female Dominion in American Reform.

7 John McClymer, "Gender and the 'American Way of Life': Women in the Americanization Movement,” Journal of American Ethnic History (Spring, 1991): 6.

8 Ann Marie Woo-Sam, "Domesticating the Immigrant: California’s Commission on Immigration and Housing and the Domestic Immigration Movement, 1910-1945” (Ph.D. diss., University of California, Berkeley, 1999).

9 Both Bessie Stoddard, member of the Los Angeles School Board, and Amanda Matthews Chase, the first home teacher in Los Angeles, for example, had been associated with College Settlement, the most important Los Angeles settlement house. College Settlement, founded in 1904, had been modeled on Hull House. By 1911, there were six settlement houses in the foreign district in Los Angeles, and most of the settlement house workers were women. Judith Raftery, Land of Fair Promise: Politics and Reform in Los Angeles Schools, 1885-1941 (Stanford: Stanford University Press, 1992), 19.

10 Michael Olnek suggests that what is most interesting in the Americanization movement is not the obvious message of patriotism and conformity, but the "symbolic delegitimation of collective ethnic identity." Michael Olnek, "Americanization and the Education of Immigrants, 1900-1925: An Analysis of Symbolic Action,” American Journal of Education (Aug. 1989): 401. 
as slightly less than white. Given the highly racialized discourse and racist practices of the times, this racial dynamic shaped the relationships between teachers and students in terms of both power and perception. The exchange between teachers and students also reflected the ironies of gender. At first, students in the early Americanization programs being instructed in citizenship were immigrant men; and, as John McClymer points out, Americanization primers and other materials used in literacy and citizenship classes "were invariant in their portrayal of the public domain of American life as an all-male preserve."11 Yet the nativeborn women who were instructing these immigrant men in the duties of citizenship were not only absent from the depictions of public life in the materials they taught, but were themselves denied full rights of citizenship until 1920, when national women's suffrage was achieved.

When Americanization programs turned to immigrant women, they were primarily envisioned either as domestic workers or as mothers. ${ }^{12}$ Immigrant mothers were seen as centrally important in providing stable homes and teaching children “American” values. In her defence of the Home Teacher Act, for example, Mary Gibson, a member of the elite Los Angeles Friday Morning Club, widow of a banker, Los Angeles School Board member, and founding member of the California Commission on Immigration and Housing, argued: "Upon the women, brave enough and strong enough to win their own political emancipation, rests the responsibility of the education and protection of these alien women; and to so establish and sustain the mother in her own domain, is to protect the state from delinquent children and an ignorant vote." 13 In her 1918 "Primer" for immigrant women, Amanda Chase warned: "Do not let your child be tardy. If you do, when he grows up he will be late at his work. Thus he will lose his

11 McClymer, "Gender and the 'American Way of Life'," 8.

12 Maxine Seller, “The Education of the Immigrant Woman: 1900-1935,” Journal of Urban History IV (1978): 307-30; Katrina Irving, Immigrant Mothers: Narratives of Race and Maternity 1890-1925 (Urbana: University of Illinois Press, 2000).

13 Gayle Gullett, "Women Progressives and the Politics of Americanization in California, 1915-1920,” Pacific Historical Review 64 (1995): 88. 
job and always be poor and miserable." ${ }^{14}$ And in her 1929 pamphlet, "Americanization through Homemaking," Pearl Ellis argued that the Mexican mother should be taught to establish values and attitudes that would help her raise a son who would be "more dependable and less revolutionary in his tendencies...The homekeeper creates the atmosphere, whether it be one of harmony and cooperation or of dissatisfaction and revolt.." ${ }^{15}$ Ruby Baughman, supervisor for immigrant education in Los Angeles, described immigrant women as "timid woman-creatures" who "would not—and often could not—seek the school for education; the school must seek them."16 The relationship between nativeborn white women and immigrant women implied in Baughman's comment is similar to Gibson's argument about the "responsibility" of the native-born teacher to "sustain" the immigrant mother in order to "protect the state." And then there is the thesis of George Sanchez, who ties the education of immigrant Mexican women to white society's desire for docile domestic workers, arguing that both the ideology of the dependable, loyal worker and the emphasis on household affairs in Americanization programs for Mexican women was intended to produce "domestic servants, seamstresses, laundresses, and service workers in the Southwest." 17

Although the Americanization movement depicted the work of teachers as transforming foreigners into responsible citizens and thus contributing to nation building, teaching in Americanization programs was not necessarily a selfless activity. For many if not most women teachers it was a means of employment and a source of some public power. As Gayle Gullett comments, the actions of these woman Americanizers were "at least partially self-serving," since by claiming a right to instruct immigrant women, "organized

14 Cited in Tyack, The One Best System, 236.

15 George Sanchez, "Go After the Women: Americanization and the Mexican Immigrant Woman, 1915-1929.” in Unequal Sisters: A Multicultural Reader in U.S. Women's History, ed. Vicki Ruiz and Ellen DuBois (New York: Routledge, 1994), 289.

16 Ruby Baughman, Elementary Adult Education, First Annual Report, Department of Immigration Education and Elementary Evening Schools, Los Angeles School District Publication No. 27, 1919, 40.

17 Sanchez, “Go After the Women,” 289. 
women thus created a political role for themselves as managers of other women's homes." 18 Yet the progressive reform impetus-the desire to help those seen as less fortunate, to extend what were seen as the benefits of "being American" to newcomers, to educate the illiterate-also emerges in the accounts of women in the Americanization movement. ${ }^{19}$ Corinne Seeds' narrative of her years working at the Avenue 21 evening night school in Los Angeles provides one example of the complex and contradictory workings of race, gender, and political idealism in the work of women Americanizers.

But Seeds' narrative can also be seen as evidence of how bodies express social hierarchies, how they respond to cultural and social change and the intrusion of difference. Memories of physical responses, of objects and space, may reveal more than words. In a recent article in the Canadian Historical Review, Joy Parr asks, “is a sensuous history within reach?” What Parr is calling for is an exploration of the bodily knowledge of historical figures, an attempt to understand their experience at a deeper level than the level of abstract language. Parr suggests that our bodies live out power-laden social relationships and cultural meanings, that they respond to the intrusion of difference in ways outside of language. Thus, she argues, we should seek to understand the "situated, material bodies" of historical actors. ${ }^{20}$ Seeds' story thus can be read as evidence both of the conditions and practices in

18 Gullet, "Women Progressives," 73.

19 John McClymer summarizes the gendered contradictions of the Americanization movement, in which disenfranchised native-born White women instructed immigrant men about the duties of citizenship and immigrant women on the sanctity of the home: "[The Americanization teacher] indoctrinated immigrant men in the proper exercise of civic responsibilities which she did not share. Meanwhile, as the teacher, she asserted a direct authority over those same men even as she taught them that public life in the United States was for men only. She also explained the proper way to run a home to immigrant women even as she actively pursued a career outside the home herself. She emphasized the primacy of motherhood and maternal duties even as her presence away from her own home demonstrated that some women could assume other responsibilities.” McClymer, "Gender and the 'American Way of Life'," 15.

20 Joy Parr, "Notes for a More Sensuous History of Twentieth-Century Canada: The Timely, the Tacit, and the Material Body," Canadian Historical Review 82, 4 (Dec. 2001): 733. 
public schools and of citizenship programs in this period, but it also tells us about the way one young white woman embodied her role as the teacher and civilizer of the strangers, the others, the foreign.

\section{Reading Corinne Seeds’ Narrative}

Corrine Seeds began her teaching career at the Mira Monte School in 1911 as a young graduate of the Los Angeles Normal School. In 1911, Mira Monte was a Los Angeles County school, outside the city limits south of Watts. Los Angeles had experienced explosive growth in the period between the 1890s and early 1900s. Between 1890 and 1909 its population increased from 50,000 to 319,000 and by 1909 it trailed only San Francisco as a Western manufacturing centre, surpassing Seattle, Portland, and Denver. ${ }^{21}$ In his classic book on the history of Los Angeles, Robert Fogelson uses fragmentation as the dominant metaphor for the emerging city, a metaphor which captures not only the geographical reality of the city, with its decentralized suburbs and reliance on automobiles, but its cultural and social life as well. Unlike the case in Eastern cities, the majority of newcomers to Los Angeles in the years before 1920 were White, native-born Americans from the East and Mid-West. In 1900, approximately twenty per cent of the residents of Los Angeles were foreign-born, but of these foreign-born residents over three-quarters were from Northern Europe or Canada. By 1920, however, the city's population increasingly included immigrants from Southern Europe, Japan, and Mexico, along with native-born African Americans moving from the South in an internal migration. Although Los Angeles did not experience as dramatic an influx of immigrants and internal migrants as did New York, Chicago, or even San Francisco, nonetheless concerns over "foreigners" were as widespread in Los Angeles as anywhere else in the country in

21 Robert Fogelson, The Fragmented Metropolis 1850-1930 (Cambridge: Harvard University Press, 1967), 123. 
this period. By 1920, just over forty per cent of children in the public schools were foreign born or had foreign-born parents. ${ }^{22}$

Conceptions of race divided Los Angeles. Immigrants from Asia and Mexico were discriminated against and segregated, as were African-Americans. Although Los Angeles was presented in the Black press as a relatively open city racially before the 1920s, at least in comparison with the South and Northeast, discrimination and racism against African-Americans marked social and cultural life. It is true that the rapid expansion of the city offered the possibility for African-Americans to buy land and build and own their own homes, but discrimination in employment and racial covenants in real estate faced African-Americans in Los Angeles as in the rest of the United States. ${ }^{23}$ Most immigrants, many AfricanAmericans, and many "Mexicans" (a term that encompassed both those of Mexican descent born in the United States and immigrants from Mexico) lived in an older section of the city known as the foreign district-“an area stretching from the original pueblo, across the river, east to Boyle Heights, then running along the railroad tracks down Central Avenue and San Pedro Street."24 Living conditions in the foreign district were dreadful. ${ }^{25}$

Seeds' description of Mira Monte, her first school, shows her sharp awareness of the lines of social difference that shaped Southern California. According to Seeds, "Negroes weren't in this district, but some of the bandits and people who were not allowed in Los Angeles City had moved there. There were also some of the

22 Raftery, Land of Fair Promise, 67.

23 Lawrence DeGraff, "The City of Black Angels: Emergence of the Los Angeles Ghetto, 1890-1930,” Pacific Historical Review 39 (1970): 343.

24 Raftery, Land of Fair Promise, 13.

25. The Mexican colonia on Utah Street, in the center of the city just east of the Los Angeles River, was described by a contemporary observer: "The land in that locality was divided into tiny lots which were rented for one or two dollars a month. On each of these lots was built a shack of hammered-out cans, old boxes, or burlap, with no yard space nor sanitary appliances of any sort. The toilets were of earth, and were used in common." Others lived in "house courts," rows of two-room apartments arranged around a courtyard with piped-in water and shared toilets. George Monroy, Rebirth: Mexican Los Angeles from the Great Migration to the Great Depression (Berkeley: University of California Press, 1999), 20-23. 
finest people I ever met, you know, working people, lovely people-I mean, like my folks." 26 In this comment on her first teaching position Seeds constructs the world of working people using two of the categories she will use throughout her life: on the one hand, "the bandits," those she saw as dangerous and other, and on the other, the "lovely" working people, with whom she identified. After two years at Mira Monte, Seeds moved to the Avenue 21 School, a city school on the east bank of the Los Angeles River, "two blocks from the railroad yard," where she taught fifth and sixth grade. Seeds presents the Avenue 21 School as mixed by race and class. "From the river bed, there were all kinds-Mexicans, and, particularly, Italians - while from the north of Highland Park Avenue and from Pasadena Avenue there were the children of the aristocratic old people of Los Angeles. So, we had quite a mixture there.”27 Here Seeds introduces the third category she will continue to use, "the aristocratic old people," the wealthy and powerful, whose children she would later teach at the University Elementary School. The principal of the Avenue 21 School was a woman, which was common in the Los Angeles elementary schools of this period. Of twenty-three teachers at the school listed in the 1919 Los Angeles School Directory, twenty-one were women, including Corinne Seeds, who then taught sixth grade. The two men on the faculty taught agriculture and manual training. ${ }^{28}$

In her second year at the Avenue 21 School, when she was twenty-four years old, Seeds was made principal of the adult night school, a typical example of the adult schools in Los Angeles in these years. The focus of the curriculum was literacy and citizenship training, but the school served as a community centre as well. Although there had been a few evening classes for illiterates in the Los Angeles schools beginning in the 1880s, organized programs for foreigners did not get under way until after the turn of

26 Corinne Seeds, UES: The History of the Creative Elementary School (Los Angeles: Oral History Project, University of California Los Angeles, 1963), 6.

27 Ibid., 15.

28 Directory of the Los Angeles City Elementary and High School Districts, 1919-1920. 
the twentieth century and only became firmly established after the creation of the California Commission of Immigration and Housing in 1913. ${ }^{29}$ Between 1911 and 1915 enrolment in LA adult evening schools almost tripled. These programs, which attracted immigrants, Mexican-Americans, and African-Americans, offered literacy classes as well as language and citizenship courses leading to naturalization. ${ }^{30}$ Although I have not found a description of the specific course offerings and activities of the Avenue 21 adult night school, they were no doubt similar to other Los Angeles adult night schools. The nearby Ann Street adult night school, for example, offered formal classes, movies on Friday nights, dances with jazz bands, and a Mexican Club, and housed a home teacher who taught hygiene and nutrition. ${ }^{31}$ As the principal of the Avenue 21 adult night school, Seeds was responsible for overseeing a similar range of activities, including both the formal curriculum of Americanization and literacy classes and recreational programs and social activities for the entire community. As was typical of the adult night schools, the Avenue 21 School had been originally established for the Americanization of immigrants, but in practice it attracted poor residents of all kinds.

Schools like the Avenue 21 adult night school were meant to transform foreigners into Americans through formal programs. One major theme in Americanization programs was unquestioning acceptance of the existing economic and political system. In this way, Americanization programs were presented as protecting society as a whole from the danger of political subversion or crime. The 1915 Annual Report of the California Commission on Immigration and Housing, for example, warned: "Unguided and unprotected, he [the immigrant] is liable to become a menace. The correction of these evils is no more than a matter of our own self protection."32 What was at stake in immigrant education, noted the

29 The first night school for foreigners seems to have been established in 1906 at the Castelar School. Baughman, Elementary Adult Education, 5.

30 Raftery, Land of Fair Promise, 76.

31 Monroy, Rebirth, 139.

32 As cited by Gullet, “Women Progressives,” 83. 
1920 Bureau of Education Bulletin, "Training Teachers for Americanization," was not just "a matter of schooling alone. It is much more than this. The immigrant is becoming either Americanized or anarchized by every experience he undergoes, every condition to which he is subjected." 33 But if there are references to the dangers of being "anarchized" in these documents, there is virtually no acknowledgement of the possible reasons for dissatisfaction or unrest-exploitative and dangerous working conditions, the denial of citizenship or membership in this imagined American community to ten per cent of the native-born U.S. population because of their race and to over half because of their gender. Nor is there any indication of the mass social movements of the time- the anti-lynching campaign, the suffrage movement, union organizing and strikes, the electoral support for Eugene Debs and the Socialists.

Although the founders of the Americanization schools in large part ignored the realities of American racism and the power of class, at times these tensions break through the official accounts. Ruby Baughman's 1919 report on elementary adult education programs in Los Angeles reveals some of these realities. When Baughman suggests that Americanization teachers hold social events as a means of building community, she also warns, "The type of recreation depends, too, on the existing racial or social barriers and the kinds and degrees of prejudice resulting therefrom. Lectures, concerts, moving-pictures are not infrequently possible where other more intimate forms of association are barred." 34 These racial and social barriers, this "prejudice," makes claims of the creation of a common American community uncertain to say the least. Consider Baughman's description of one school in a "thoroughly cosmopolitan neighborhood, composed mostly of American wageearners, but having a sprinkling of well-to-do families who look with utter contempt upon their less fortunate neighbors, foreign,

33 John Mahoney, Training Teachers for Americanization (United States Bureau of Education Bulletin No. 12, 1920), 14.

34 Baughman, Elementary Adult Education, 34. 
colored, and even the laboring class of Americans."35 Baughman gives no advice as to how Americanizers were to deal with the "utter contempt" of these privileged native-born Whites.

If Americanization materials seldom acknowledge the depths of racism in American society, they are also striking in their failure to acknowledge immigrant ethnic or religious community groups - the groups that, in practice, provided the strongest collective expression and support for the immigrants. As Linda Gordon argues, the relationship between the state and groups envisioned as needy was not completely controlled by the state; Gordon argues that in many situations groups and individuals negotiated their interaction with state agencies to meet their own needs. ${ }^{36}$ Judith Raftery's study of schools and communities in Los Angeles in the period 1885-1941 makes a similar point. Raftery argues that immigrant groups expressed their own selfdetermination by making demands for more educational services from the city school board, "requests for additional services, such as rooms to conduct native language classes, after-school playgrounds, or auditoriums for national celebrations, and, in most cases, the board granted the requests." ${ }^{\text {,37 }}$

Ruby Baughman's account supports this view that families were supportive of programs in which they participated themselves:

Our most successful evenings have been those in which the program was given by the people themselves or their children. No matter how simple the event, the crowd was larger and more appreciative than when a noted person was brought out from town - proving again that what people do for themselves means far more to them than that which is done for them. ${ }^{38}$

\footnotetext{
35 Ibid., 36.

36 Linda Gordon, "Family, Violence, Feminism, and Social Control," in Women, the State, and Welfare, ed. Linda Gordon (Madison: University of Wisconsin Press, 1990), 195.

37 Raftery, Land of Fair Promise, 3.

38 Baughman, Elementary Adult Education, 38.
} 
By the early 1920s local schools allowed Mexican groups to use school auditoriums to celebrate Cinco de Mayo, African-Americans to hold meetings of the NAACP, Russian and Japanese cultural organizations to hold meetings on school grounds. Individual students in Americanization programs used the offerings of the schools for their own ends as well, particularly citizenship classes which could be used toward naturalization. And literacy programs frequently attracted native-born African-Americans or MexicanAmericans who had not benefited from public schooling and who were discriminated against in a racist society. Thus the intent of Americanization might be control, assimilation, and social discipline, but both immigrants and native groups could use the programs and institutional spaces for other ends. Moreover, although advocates of Americanization seemed to assume that only through organized programs and classes would immigrants learn "how to be American," of course immigrants were powerfully attracted to American popular culture - to baseball, movies, radio, and jazz - a process of cultural identity formation that was taking place across a wide spectrum of society, not just in formal classrooms or programs.

Seeds' account of her years teaching at the Avenue 21 School captures many of the contradictions inherent in Americanization programs. One of the most striking aspects of her narrative is the contradiction between her sympathetic view of her students and their community and her sense of her own race privilege. One of the dominant themes in her account is her respect for her students and their families as hard-working people. This strong sympathy doubtless reflects her own family upbringing. Her father was a carpenter, a union member with a strong labour consciousness. Her narrative often shows a recognition of how hard people work and a sense of compassion for working people. For example, here is her description of teenagers who had to attend the night school because they worked during the day:

Now, the night school was established mainly for the people who wished to become citizens, but there was also a group of children who had to work in the daytime. Most 
of them drove milk carts in the morning-getting up way early. Oh, they were God-forsaken bunch of young people-teenagers, you know. Those under eighteen (fourteen to eighteen) had to attend night school. Those poor kids! What we taught them was nil. ${ }^{39}$

Seeds not only calls them "those poor kids," but she understands the nature of their work and what it must mean in terms of a physical toll on them. It is no wonder that what the teachers taught them was probably "nil."

But Seeds' sympathy for the working class is mixed with a sense of her own cultural superiority, often expressed around racial difference. For example, consider this description of the students who came to the night school: "Oh, they were funny people-old Negroes, you know, that wanted to learn to read, and all those poor tired people that came to get their citizenship papers." 40 Her use of the word "tired" here to me implies a recognition of their hard physical work. They are not just "those poor people," but "poor tired people," tired, because they are working at exhausting working-class jobs. And yet, what does Seeds mean by the word "funny," when she describes "old Negroes" who wanted to learn to read? It is hard to understand what Seeds could have meant here-surely not amusing, not odd. The word "funny" echoes other passages in her oral history dealing with African-Americans. She notes of one African-American man: He “didn't have any brains at all; he was a clown." ${ }^{41}$ She often uses Black dialect when she describes African-American speech, a choice that gives an effect of naïveté or cultural lack. Or consider this comment she attributes to her father: "My father said that, when these five [African-American men] came to night school, it was like a comic opera to see them coming up the steps." ${ }^{2}$ In using these terms-comic, clown, funny-Seeds employs the familiar and demeaning cultural image

39 Seeds, Creative Elementary School, 18.

40 Ibid., 21.

41 Ibid., 31.

42 Ibid., 32. 
of Sambo, of the simple Black man. She is speaking through a racist discourse that positions her as superior and makes childlike (and therefore unthreatening) the African-American men she taught. She does not refer to any other ethnicity in these terms.

Another example of the complexity of Seeds' racial and cultural positioning is shown in the following passage in which she describes her work teaching "poor old Mexicans," whom she "loved."

I loved the people though, and I even went and taught in the box cars where they brought the poor old Mexicans. They lived in the box cars, while they worked for almost nothing in the canning factory. That's what we were doing in those days - importing those poor people and exploiting them. The women would sit on the steps, and in the summer I tried to recruit them. I spent six weeks of my time for two whole summers wearing white dresses that Mother kept washed and ironed all the time. I would sit on the steps with an Italian woman, maybe help her to know a few words, and try to keep them out of the hands of the people that exploited them. I even begged the canning factory man to let me teach some English to the men, but he worked them ten hours and often kept them afterward. ${ }^{43}$

Here Seeds is explicit about the brutal working conditions of these immigrants: "That's what we were doing in those days, importing those poor people and exploiting them." They worked "for almost nothing." And she uses the term "exploited" again when she describes her attempt to teach the Italian women English, "to keep them out of the hands of the people that exploited them." The men were unable to attend a literacy class she wanted to teach because of the long hours imposed upon them by their floor boss. And yet even in this sympathetic picture, Seeds inserts the sentence about 
wearing a clean, white dress each day, one her mother washed and ironed for her. What is the meaning of this clean white dress?

One of the most striking themes in the Americanization materials is the trope of cleanliness and domesticity. The interest in hygiene and sanitation in public school curricula has often been pointed to as an example of the totalizing intent of Americanization to transform both children and their parents by cleansing them of their ethnicity through cleansing their bodies. While the social disciplining of bodies is clearly evident in this rhetoric of cleanliness, it is also important to examine the material results of the progressive advocacy of public health programs. In Los Angeles, the progressive era saw the introduction of school nurses, yearly physical examinations for schoolchildren, and penny lunches, first made available in $1909 .{ }^{44}$ By the late 1920s, the results of these public health campaigns were dramatic. George Sanchez points out:

Hygiene saved children's lives, and milk made them much healthier. In 1923, when the rate of infant death before one year of age for Mexicans in Los Angeles stood at 250.3 per 1,000 , or about one in four, the county initiated an intensive program of maternal and infant hygiene. By 1929 the rate had fallen to 104.5 , or about one in ten. ${ }^{45}$

Although this rate remained about double that of the White population, this was still a remarkable improvement in only six years. Thus the progressive reform impetus that underlay Americanization meant not only the imposition of cultural values, but, as John McClymer points out, it was "also a matter of prevention of exploitation, of good housing, of clean milk for babies, of adequate wages, of satisfactory industrial conditions, of the spirit of neighborliness between Americans, old and new."46

44 Raftery, Land of Fair Promise, 40.

45 Monroy, Rebirth, 197.

46 McClymer, “Gender and the 'American Way of Life',” 11. 
But if public health programs provided real benefits, the rhetoric around them reveals the depth of a racialized discourse that equated foreignness, dirt, and corruption. Disorder and dirt were signs not only of foreignness, but of moral degeneracy. Ruby Baughman's 1919 report of Americanization programs in Los Angeles, Elementary Adult Education, for example, describes a class of fifteen Mexican women from a Southern Pacific railroad camp:

In order to have a good meeting place for the class one woman cleaned up her house and rearranged the furniture to make more room. The teacher was tremendously encouraged when another mother brought in her baby whom she had taught to say, "I sweep, I scrub, I mop," vigorously gesticulating with the broom and the mop as she went. ${ }^{47}$

Baughman's description of English classes at the Pullman Car Cleaning plant in Los Angeles provides another example of this conflation of cleanliness and Americanism. According to Baughman's account, women who worked as cleaners for Pullman Cars were unable to attend evening school, so the Americanization teacher arranged to have them study on the lunch break. After noticing the progress made by the women, the foreman asked for an evening class for men in a nearby camp. Baughman continues:

The "camp" is a group of neighboring houses all occupied by workmen engaged in Pullman Car cleaning. When they found that a teacher would be provided, the men under the leadership of the foreman, went to work with a will. They cleared the only available room in their camp, which was the basement of one of the houses. It was cleaned until it shone, fresh new paper was put on the walls, and the floor covered with rugs. The men themselves built tables,

47 Baughman, Elementary Adult Education, 44. 
chairs, and benches, and every convenience that they could think of was installed. Although their work during the war period has been very heavy, owing to the extra work of cleaning troop trains, these men have persisted. Seven of them have not missed an evening since the opening of the class, except when working “overtime."48

The act of cleaning and furnishing a classroom is evidence of the men's desire to learn English and to become American, and of their moral uprightness as well (they are tired because they are working overtime to clean troop trains).

Stories of immigrants coming to understand the value of cleanliness and tidiness served to demonstrate their transformation into Americans. Dirt and disorder were marks of foreignness, of otherness. Seeds' own cleanliness, her white clothes, established her own moral superiority. For example, here is her description of a Mexican family living in a boxcar:

One summer I decided I'd go and teach the Mexican women some English. They mixed their foodstuff on the floor in the boxcar. Their hair was hanging down so it almost touched the floor, and I could see the bedbugs walking across the floor and their hair full of nits. I never got any nits or bedbugs, but my mother met me every afternoon in the hall at five o'clock with sulfur that she made me walk through. Then she would make me put on all clean clothes. She said, “That wasn't what I raised you for." 49

The details of this passage - the food on the floor, the women's hair almost touching the floor, bedbugs and nits-are not framed as the result of poverty or tied to the exploitation that forced these people to live in a box car, but presented on a more personal level in terms of Seeds' own bodily experience. They are responses to

48 Ibid., 9.

49 Seeds, Creative Elementary School, 28. 
conditions of poverty, but they also seem to be experienced as markers of class. She recounts how her mother, who was the one who washed and ironed Seeds' white dresses, made her walk through sulfur and change her clothes after coming home from teaching. But Seeds doesn't comment critically on her mother's actions or her comment "that wasn't what I raised you for"; instead, Seeds lets them stand-and perhaps stand in for her own sense of class and race superiority.

Another theme in Seeds' description of poor and immigrant families centres around odour or insects. For Seeds, these, like uncleanness, seemed to be a mark of difference and foreignness. Here, for example, is a description of a Japanese community she visited at the request of a home teacher, Miss Hasagawa, whom Seeds describes as a "high born Japanese."

That place was simply jammed. The babies, the children, had flies crawling over their eyelids, and their eyes didn't blink. After seeing those children and those Japanese babies in the mother's sack, who had their legs this way with the baby in between-oh, that time I went home and bathed. Usually I never do that after contact with Japanese people, but you see, they lived in Tropico, this sort of shanty town that was out somewhere between Glendale and San Fernando. ${ }^{50}$

Here it is insects - this time flies - that cause Seeds to go "home and bathe." It is interesting that at the end of this passage she ties her reaction to their class: "Usually I never do that after contact with Japanese people.” And Miss Hasagawa, a fascinating figure, is not explained or mentioned again. There were few JapaneseAmerican teachers in California at this time; in some places Japanese-American children were sent to segregated schools. Miss Hasagawa is presented as a home teacher, implying she was hired by the Los Angeles school district. Where had she been educated?

50 Ibid., 35. 
What circumstances led to her hiring as a home teacher? Seeds was later highly critical of the Japanese internment during the Second World War; she taught and supported Japanese and JapaneseAmerican students at UCLA. But she does not frame this memory in terms of her later experiences; here the dirt, the flies, the odour, mark poverty, but also foreignness and difference.

Seeds provides a similar description of teaching AfricanAmericans. She describes how one day an African-American woman asked her to hold a literacy class in the African-American woman's home in the Black community. This story is fascinating in documenting the desire for education and literacy on the part of adults in the African-American community, and it also suggests their trust in Seeds herself. Something about Seeds led this woman, whom Seeds calls "the leader of the Negroes," to approach Seeds and ask for her help. But it also reveals Seeds' own racial attitudes:

"Now, I thought this all over," [the African- American woman] said. "Next Wednesday, you come to my house at one o'clock and I will have the Negroes in this neighborhood assembled.” I didn't like it very much; I didn't really know what was going to happen, but when I got there, there were about fifty Negroes packed in a very small house. They all wanted to know how to read and write. The kids were all assembled on the outside raising a lot of ruckus. I don't know how I ever did it, except I had a lot of pencils and paper. It was a mess. She'd baked cakes, and she had lemonade, which didn't have any ice in it. So, there, I knew what it was to eat and drink with a group of people that were not of my race. I must admit I went home and took a bath afterwards, because it is something for one person to be surrounded in the beginning like that. I don't know whether it's instinct or what it is. Of course, the odor was terrific in there. 
However, this women never had any odor herself, nor did Mattie Lafayette. ${ }^{51}$

In this passage, Seeds seems aware of the problematic nature of her reaction and seeks to defend it ("I don't know if it's instinct or what it is...”) Once again, she comments on odour, but makes a point of excluding the woman who had invited her and another African-American woman, Mattie Lafayette, from this charge. Seeds gives no other evidence of uncleanness in this house; perhaps the absence of ice in the lemonade is meant to show cultural lack. But once again, she goes home to bathe, cleansing herself of contact with difference. After the meeting at the house, Seeds says she continued to hold literacy classes, but only at the school. Later in her oral history the interviewer asked her if she ever got over her "first revulsion in contact." Seeds replied, "Oh, yes. You see, when I got them up to the school. I mean, when they weren't all swarmed together, there was no odor. I'm very susceptible to odors. Oh yes, then, I just adored them, because I'd like anything that could be taught." ${ }^{2}$ Seeds may well have adored her students, but it is striking that in this passage she comments that she could teach "anything," not "anyone," as though a student were an object and not a human being like herself.

Seeds' attitude towards her students thus was a mix of physical unease, compassion, objectification, and cultural stereotyping. Contrast her depiction of Black men as "clowns" with this description of Mattie Lafayette, who had "the best- blooded stock in her. She was a queen.”

I grew to be very fond of them. One of them was Mattie Lafayette, who was then sixty-five years old. She lived in a house which was made entirely out of, I guess, wooden boxes, with tin cans that she had cut and made into a roof. She made her living by doing the most beautiful washing and ironing I have ever seen in my life...When I was 
making some rounds of the neighborhood I used to sit and watch her iron the ruffles. She was born a slave and had the best-blooded stock in her. She was a queen. She walked with this great basket of clothes on her head and her back wasn't bent, even at sixty-five. ${ }^{53}$

In this passage, Seeds draws upon cultural images of the Black woman as noble earth mother. This woman undertakes hard labour, but her back is not bent, she is "a queen." "54 Seeds' rhetorical calling forth of the noble black granny who "was born a slave" with the bearing of a “queen” recalls Hortense Spillers' comment that Black woman are seen through "markers so loaded with mythical prepossession that there is no easy way for the agents buried beneath them to come clean." 55

Seeds clearly wants to remember her experiences teaching in the adult evening school as positive. She is the benevolent transmitter of culture and citizenship. She describes the classroom of the adult evening school: "We had lovely blackboards and lots of chalk and I used to take their hands in mine and help to train them." 56 In this image, she physically guides them to literacy. This positioning of herself as guiding students to literacy occurs in another story she tells of an elderly African-American woman. Seeds is about to leave for New York to study at Teachers College:

"Miss Seeds," [the African-American woman] said, "Ah knows you's going away. You know, I just want to tell you something. Last Sunday I took out my Bible and," she said, “do you know, I read.” Then she said, “Ah’s got

53 Ibid., 31.

54 While it is true that there were African monarchies and that the tradition of African royalty continued to exist in African-American memory, it is unlikely that Seeds was suggesting this historical continuity here.

55 Hortense Spillers, “Mama’s Baby, Papa’s Maybe: An American Grammar Book,” Diacritics (Summer 1987): 65.

56 Seeds, Creative Elementary School, 31. 
the key to the white man's Bible. I want to thank you." Wasn't that something? ${ }^{57}$

In these stories of her contact with immigrant, Mexican-American, and African-American students, Seeds presents herself as the benevolent and powerful teacher, who holds and dispenses cultural knowledge and is thanked by grateful students. It is Seeds who is in the position of power. The markers of odour, insects, dirt, of noble slaves and clownish men are all set out in contrast to the figure of the gracious loving teacher in a white dress.

If Seeds fails to explore the dynamics of racism and class privilege, she equally ignores male privilege or her subordinated social place as a woman. When she speaks of her experiences at the Avenue 21 School, she does not discuss her subordinate position as a woman working in a male-dominated world. On the one hand, this may not have been an immediate issue for her. Although she mentions a male superintendent, Dr. Bettinger, in passing, she does not present him as having much involvement with her work. The principal of Avenue 21 was a woman, as were the major figures in the Americanization movement in Los Angeles. So Seeds may very well have moved within a "female dominion" in these years at the Avenue 21 School. On the other hand, many of her students were boys and men and she speaks of the tension between herself as a woman in authority and the young men who participated in the school's programs.

Seeds describes numerous gangs in the neighborhood. The school hired men, among them male college students, to monitor the school playground. According to Seeds' account, some of these young men who were supposed to maintain control were in fact afraid of the gangs, but, Seeds says, she wasn't. "You know," she says, "some of them [the gang members] had young brothers in my room, and I think they never would have touched me." Here she draws on her relationship with families and her standing as a white woman teacher to explain her power. She makes a similar point in

57 Ibid., 36. 
the following story:

The boys did such awful things. We had a mortuary across the street and on Halloween they got all the tin cans they could find, borrowed the hearse and tied them on it. Then a great lot of them pulled the hearse up and down the street. Somebody played dead inside and they beat the drums and everything. Mr. Bettinger came out and saw it, and the mortician said to me, "Miss Seeds, it's just not decent of them to do that with the hearse.” So, I ran down the street and caught them and said, "Boys, Mr. so-and-so is upset because it's really sort of sacrilege, he believes, to take the hearse out. Won't you take it back?” It went back. They said, "Anything to oblige you."58

This presentation of her power over the tough young men is elaborated in another tale. The gang liked to come into the school and set off the fire alarm. One night, Seeds says, she stopped them.

I saw the gang assemble, and I thought, "Oh, dear me, now here it is again, and what'll I do?” because, oh, they were so much bigger than I and so tough. They were really tough. While I wasn't afraid for myself and knew they wouldn't touch me, because they had a code that they wouldn't touch a woman, I just didn't know what to do to stop them. Hickey [the gang leader] came dashing through past the door, hoping I wouldn't see him. I ran, and he saw me coming, but as he reached for the bell he slipped and fell. His gang came by and enjoyed seeing their leader that way. They ran out and told everybody that Miss Seeds knocked him down. ${ }^{59}$

Here Seeds acknowledges the physical strength of the young men ("they were so much bigger") but at the same time reiterates her 
belief in her own moral strength. They would not "touch her," she says, because of their "code." How do we understand this claim of a code of male chivalry in the light of evidence of widespread violence against women at this time? Is Seeds drawing on race privilege here? She does not indicate the ethnicity of these young men; they may very well have been native-born whites. More likely, she is calling upon class privilege and its intersection with gender, her location as woman teacher, to make this claim. What does this story suggest about the meaning of Americanization work for young white women like Seeds, who were, after all, still disenfranchised and living within a patriarchal world?

\section{Conclusion}

Corinne Seeds' narrative suggests a great deal about the way race, gender, and class were lived in Americanization programs. But while her account provides a striking account of one woman's response to cultural and racial difference, it does not reveal the broader history of the Americanization movement in Los Angeles. A number of historians have noted that despite the widespread concern about the crisis caused by immigration and calls for Americanization programs, a very small percentage of immigrants actually attended them. ${ }^{60}$ A 1920 survey of Americanization programs in Los Angeles showed that of 3,448 people who entered Americanization programs, only 322 completed them-less than ten per cent. ${ }^{61}$ Although Judith Raftery argues that teachers in Los Angeles "continued to visit immigrant homes, draw up legal documents, and preach understanding and even limited pluralism well into the 1930's," by the end of the First World War the Americanization movement faced the growth of a nationwide reactionary, anti-state, and anti-foreigner sentiment. ${ }^{62}$ In 1922 the Better American Federation, which was associated with the

60 Seller, “The Education of the Immigrant Woman," 307-30.

61 Gullett, “Women Progressives,” 90.

62 Raftery, Land of Fair Promise, 198. 
conservative Merchants and Manufacturers Association, was organized in Los Angeles. The Federation attacked unions, regulatory commissions, and progressive programs in general, including Americanization programs. ${ }^{63}$ After conservatives won control of the school board in the 1923 election, Los Angeles began to cut services, including neighbourhood adult night schools.

With the passage of the restrictive Johnson-Reed act in 1924, conservative administrations sharply cut funding for Americanization programs throughout the country. After 1924, new groups of immigrants no longer arrived each year, while those already in the United States increasingly were left to their own devices. And of course, only five years after the passage of the Johnson-Reed Act came the great stock market crash of 1929 and the onset of the Great Depression. But whether there were formal programs to "Americanize" newcomers or not, the process of American racialization continued its work, with some groups fading into whiteness, carrying only a kind of culinary ethnicity, while others more sharply emerged as "non-white," thus falling into existing patterns of American racism.

If Corinne Seeds' narrative does not document this broader history of Americanization, it does reveal the workings of race and gender as they were embodied (or remembered) by one white woman teacher. Historians have tended to take for granted the middle-class status of these white women reformers. While this was largely true for the generation of women who founded the settlement house movement and who were members of women's clubs, the women teachers in urban public schools in the progressive era who made up the bulk of Americanization teachers were in most cases only marginally out of the working class. So their relationship to the diverse populations they taught, both in public school classrooms and in Americanization programs, was contradictory. As teachers, they were themselves the subject of direct surveillance and supervision; as women, they did not have full citizenship until 1920. Like Seeds, they symbolized the power 
of the state and native American culture, but their own actions were circumscribed by their position as teachers in an increasingly bureaucratic state and their lives as women within patriarchy.

However strong Corinne Seeds' sympathy for workers and her desire to build a more progressive society, her body tells a more conflicted story. As Joy Parr argues, "Daily we learn through our senses; we act through routines and react by reflexes so practised they seem inborn; our time and place inscribe our bodies with habits that, in time, elude conscious awareness. This learning is what makes us most deeply comfortable in ourselves and haunts us when...our physical and social circumstances change."64 Corinne Seeds' unconscious sense of her own racial and moral superiority lay deeper than speech, in the very way she experienced the physical world, in her acute sense of smell and touch, her embodiment in her clean white dress. All of these sensations provide evidence of the corporeal knowledge that "marks her of her time," to paraphrase Joy Parr. Seeds' narrative shows us how white women teachers at times could call upon the authority of the position of teacher to assert themselves; but in a deeper, more embodied sense, how they lived the power of whiteness.

64 Parr, “Notes for a More Sensuous History,” 720. 